\title{
Penerapan Model Pembelajaran Kooperatif Co-Op Co-Op untuk Meningkatkan Prestasi Belajar Yadnya Secara Online
}

\author{
Gede Suartina ${ }^{1 *}$ \\ ${ }^{1}$ SMK Negeri 2 Singaraja, Singaraja, Indonesia
}

\author{
A R T I C L E I N F O \\ Article history: \\ Received 17 February \\ 2021 \\ Received in revised form \\ 30 March 2021 \\ Accepted 10 April 2021 \\ Available online 02 May \\ 2021 \\ Kata Kunci: \\ Co-Op Co-Op, Prestasi \\ Belajar \\ Keywords: \\ Co-Op Co-Op, Learning \\ Achievement
}

\begin{abstract}
A B S T R A K
Penerapan model pembelajaran yang kurang inovatif dapat menyebabkan rendahnya prestasi belajar siswa, sehingga diperlukan model pembelajaran yang dapat meningkatkan prestasi belajar siswa khususnya materi yadnya. Tujuan penulisan penelitian tindakan kelas ini adalah untuk menganalisis penerapan model pembelajaran Kooperatif Co-Op Co-Op untuk meningkatkan prestasi belajar yadnya secara online. Penelitian ini termasuk kedalam jenis penelitian tindakan kelas. Subyek penelitian adalah siswa kelas $X$ yang berjumlah 32 orang siswa, sedangkan objek dari penelitian ini adalah prestasi belajar yadnya. Metode pengumpulan datanya adalah pemberian tes prestasi belajar kepada siswa. Teknik analisis datanya adalah deskriptif kuantitatif. Hasil penelitian ini adalah pada awalnya diperoleh nilai rata-rata 68,44, pada siklus I menjadi 71,56 dan pada siklus II menjadi 81,09 dan ketuntasan belajar pada awalnya dengan ketuntasan $59,38 \%$, pada siklus I menjadi $68,75 \%$ dan pada siklus II menjadi $96,88 \%$. Kesimpulan yang diperoleh
\end{abstract} dari penelitian ini adalah model pembelajaran Kooperatif Co-Op Co-Op dapat meningkatkan prestasi belajar yadnya secara online. Implikasi penelitian ini adalah penerapan model pembelajaran kooperatif Co-Op Co-Op dapat melatih siswa agar aktif, antusias didalam pembelajaran dan dapat memahami materi yang diajarkan sehingga prestasi belajar siswa menjadi meningkat.

\section{A B S T R A K}

The application of less innovative learning models can lead to low student achievement, so a learning model is needed that can improve student achievement, especially the material of yadnya. The purpose of writing this classroom action research is to analyze the application of the Cooperative CoOp Co-Op learning model to improve Yadnya's online learning achievement. This research belongs to the type of classroom action research. The research subjects were students of class $X$ totaling 32 students, while the object of this study was the learning achievement of Yadnya. The data collection method is to provide learning achievement tests to students. The data analysis technique is descriptive quantitative. The results of this study are initially obtained an average value of 68.44, in the first cycle it becomes 71.56 and in the second cycle it becomes 81.09 and completeness of learning initially with completeness of $59.38 \%$, in the first cycle it becomes $68.75 \%$ and in the second cycle to $96.88 \%$. The conclusion obtained from this research is that the Co-Op Co-Op Cooperative learning model can improve Yadnya online learning achievement. The implication of this research is that the application of the Co-Op Co-Op cooperative learning model can train students to be active, enthusiastic in learning and can understand the material being taught so that student learning achievement increases.

\section{Pendahuluan}

Pendidikan yang berkualitas merupakan faktor penting dalam pembangunan di era globalisasi saat ini. Pengalaman dibanyak negara menunjukkan sumber Daya Manusia (SDM) terutama pendidikan yang berkualitas lebih penting dari sumber daya alam yang melimpah (Ardianingsih et al., 2017; Makaborang, 2019; Purwanti, 2017). Sumber daya manusia terutama pendidikan yang bermutu hanya

Copyright (C) Universitas Pendidikan Ganesha. All rights reserved 
dapat diwujudkan dengan pendidikan yang bermutu pula. Maka dari itu, inovasi atau pembenahan di bidang pendidikan khususnya dalam proses pembelajaran sangat diperlukan agar kualitas pendidikan terus meningkat.

Pembelajaran yang berlangsung di sekolah sekarang ini masih terdapat guru yang menerapkan pembelajaran konvensional. Didalam pembelajaran konvensional siswa hanya sebagai penerima informasi saja, siswa belajar secara individu, serta siswa penilaian yang digunakan hanya berupa tes saja. Pendidikan dimanapun dan kapanpun masih dipercaya orang sebagai media ampuh untuk membentuk kepribadian anak ke arah kedewasaan. Pendidikan agama adalah unsur terpenting dalam pendidikan moral dan pembinaan mental (Khodijah, 2018; Lestari, 2018; Suanthara, 2018). Pendidikan moral yang paling baik sebenarnya terdapat dalam agama karena nilai-nilai moral yang dapat dipatuhi dengan kesadaran sendiri dan penghayatan tinggi tanpa ada unsur paksaan dari luar, datangnya dari keyakinan beragama. Karenanya keyakinan itu harus dipupuk dan ditanamkan sedari kecil sehingga menjadi bagian tidak terpisahkan dari kepribadian anak sampai ia dewasa.

Pendidikan agama di sekolah mendapat beban dan tanggung jawab moral yang tidak sedikit apalagi jika dikaitkan dengan upaya pembinaan mental remaja. Usia remaja ditandai dengan gejolak kejiwaan yang berimbas pada perkembangan mental dan pemikiran, emosi, kesadaran sosial, pertumbuhan moral, sikap dan kecenderungan serta pada akhirnya turut mewarnai sikap keberagamaan. Masa remaja adalah usia transisi dari masa kanak-kanak menuju masa kematangan dewasa. Kematangan dewasa secara psikologis adalah keberhasilan seseorang dalam mencapai a sense of responsibility serta dalam memiliki filsafat hidup yang mantap (Lestari, 2018; Setyaningsih et al., 2020; Suanthara, 2018). Salah satu materi yang pokok sebagai pengisi filsafat hidup adalah agama. Pendidikan Agama Hindu dan Budi Pekerti diberikan kepada siswa secara terencana dan berkesinambungan dalam rangka pengembangan kemampuan peserta didik atau siswa untuk memperteguh keimanan dan ketaqwaan dalam meningkatkan sradha dan bhakti siswa terhadap Ida Sang Hyang Widhi Wasa dan dapat berprilaku mulia yang mencangkup etika, budi pekerti dan moral sebagai perwujudan dari pendidikan Agama Hindu dan Budi Pekerti (Lestari, 2018; Selasih, 2016; Widyanto, 2020). Hal ini juga untuk meningkatkan potensi spiritual yang mencangkup pengenalan, pemahaman dan penanaman nilai-nilai keagamaan serta pengamalan nilai-nilai tersebut dalam kehidupan individual maupun kolektif kemasyarakatan.

Keberhasilan proses pembelajaran lebih banyak ditentukan oleh kemampuan guru dalam mengelola proses pembelajaran tersebu. Terkadang ada guru yang disebut pintar tetapi lemah dalam menyampaikan pengetahuan dan pemahaman yang ada dalam dirinya maka tentu proses pembelajaran tidak akan berhasil dengan baik. Kadang ada guru yang disebut tidak terlalu pintar tetapi dalam menyampaikan dan mengelola pembelajaran lebih kreatif dan memahami cara penyampaiannya bisa jadi menyebabkan proses pembelajaran akan berhasil dengan baik. Di antara keduanya tentu yang paling sesuai adalah memiliki kemampuan profesionalisme keguruan dan mampu menyampaikan dengan baik demi terciptanya proses dan tujuan pembelajaran yang diharapkan untuk mampu meningkatkan ketakwaan terhadap Tuhan Yang Maha Esa (Anggreni, 2016; Gateri, 2016; Sukrawati, 2018).

Berdasarkan pengamatan awal di kelas X Kuliner 4 SMK N 2 Singaraja, peneliti menemukan fenomena bahwa masih rendahnya prestasi belajar siswa pada materi Yadnya. Hal itu terlihat dari masih banyaknya siswa yang mendapat nilai di bawah kriteria ketuntasan minimal (KKM) yang telah ditetapkan. Nilai kriteria ketuntasan minimal (KKM) di SMK Negeri 2 Singaraja adalah 70 didapat nilai rata-rata siswa kelas X Kuliner 4 pada materi Yadnya mata pelajaran Agama Hindu dan Budi Pekerti, baru mencapai 68,44 dan Prosentase kelulusan baru mencapai 59,38\% Hasil tersebut tentu tidak sesuai dengan harapan keberhasilan pendidikan yang ditetapkan. Tentang pelajaran yang disampaikan, jika pelajaran sempat diterima peserta didik dan belum berhasil, boleh jadi penyebabnya adalah keterbatasan kemauan guru dalam menerapkan semua keilmuan yang dikuasai demi pencapaian hasil maksimal dalam pembelajaran. Sedangkan dari pihak siswa banyak dipengaruhi oleh kebiasaan belajar mereka yang rendah akibat pengaruh luar, kemampuan ekonomi orang tua dan kebiasaan belajar yang belum banyak dipupuk. Namun apapun yang menjadi latar belakang permasalahan, apabila hal ini dibiarkan berlarut tentu berakibat tidak baik bagi kelangsungan pendidikan peserta didik dan bagi perkembangan mutu pendidikan bangsa Indonesia. Karena hal tersebut di atas merupakan sesuatu yang mendesak untuk dipecahkan menuntut guru lebih kreatif dan inovatif mencari jalan keluar dengan melakukan penelitian yang berguna demi meningkatkan kualitas pendidikan di sekolah.

Melihat kesenjangan antara harapan yang telah disampaikan dengan kenyataan lapangan sangat jauh berbeda maka perlu upaya memperbaiki mutu pendidikan utamanya pada materi yadnya mata pelajaran Agama Hindu dan Budi Pekerti. Salah satunya adalah perbaikan pembelajaran dengan menggunakan model pembelajaran Kooperatif Co-Op Co-Op. Pembelajaran kooperatif dapat dijadikan sarana bagi guru untuk mengajarkan berbagai keterampilan sosial yang dibutuhkan siswa untuk hidup dan bekerja sama. Pembelajaran kooperatif menurut (Henri et al., 2018; Sunanto et al., 2020; Yeshy et al., 
2017) memungkinkan siswa untuk berinteraksi secara lebih bebas, mengembangkan kecakapan sosial yang lebih besar, dan berpartisipasi dengan lebih aktif dalam pembelajaran matematika.

Pembelajaran kooperatif membuat siswa yang ditempatkan bersama dalam pembelajaran kelompok akan bekerja sama setelah jangka waktu tertentu, membentuk ikatan dengan yang lainnya, dan memungkinkan untuk terlibat dalam percakapan yang lebih mendalam mengenai konten matematis, akibatnya, siswa akan mendapatkan manfaat dengan memperoleh pemahaman yang lebih mendalam mengenai konsep matematis (Karom et al., 2014; Sihombing, 2018; Suparmi, 2013).

Metode-metode dalam pembelajaran kooperatif memiliki intervensi sosial, maka seharusnya dapat menghasilkan pengaruh sosial. Menurut (Andriyani \& Saputra, 2019; Maryanti, 2018; Naldi \& Susanti, 2018) pembelajaran kooperatif didasari oleh teori konstruktivis sosial sehingga siswa dapat lebih memahami suatu materi dengan saling berinteraksi. Pembelajaran kooperatif dapat menjadi salah satu model pembelajaran yang dapat digunakan karena melatih siswa untuk saling bekerjasama dengan teman dan melatih siswa untuk saling berkomunikasi. Pembelajaran kooperatif (cooperative learning) merupakan suatu teknik pembelajaran yang mengeksplorasi keaktifan siswa untuk berinteraksi dalam satu kelompok kecil (Cahyaningsih, 2018; Santriana Son, 2019; Wintari et al., 2014).

Dalam sistem belajar yang kooperatif, siswa belajar bekerja sama dengan anggota lainnya. Dalam model ini siswa memiliki dua tanggung jawab, yaitu mereka belajar untuk dirinya sendiri dan membantu sesama anggota kelompok untuk belajar. Siswa belajar bersama dalam sebuah kelompok kecil dan mereka dapat melakukannya seorang diri. Menurut (Mamanda, 2018; Murdika, 2018; Suryanata, 2017) Dalam konteks pengajaran, pembelajaran kooperatif adalah membentuk kelompok- kelompok siswa yang bekerja sama untuk mencapai tujuan bersama dan saling meningkatkan pemahaman bersama. Jenis pembelajaran kooperatif yang digunakan dalam penelitian ini adalah tipe $\mathrm{Co}-\mathrm{Op} \mathrm{Co}-\mathrm{Op}$. Model pembelajaran kooperatif memiliki banyak tipe, salah satunya adalah kooperatif tipe $\mathrm{Co}-\mathrm{Op} \mathrm{Co}-\mathrm{Op}$, dalam pembelajaran siswa diharuskan untuk aktif berdiskusi dengan teman untuk menyelesaikan suatu permasalahan individu maupun kelompok (Alirezaei \& KhoshAlhan, 2014; Maryanti, 2018; Togatorop, 2017). Selain melatih siswa untuk berdiskusi, model kooperatif tipe $\mathrm{Co}-\mathrm{Op} \mathrm{Co}-\mathrm{OP}$ juga melatih siswa untuk bertanggung jawab pada tugas yang diberikan.

Pembelajaran kooperatif tipe $\mathrm{Co}-\mathrm{Op} \mathrm{Co}-\mathrm{Op}$ adalah pembelajaran yang mengutamakan diskusi kelompok dan diskusi antar kelompok (Andriyani \& Saputra, 2019; Togatorop, 2017; Yeshy et al., 2017). Pada awal pembelajaran dilakukan diskusi kelas yang berpusat pada siswa. Selanjutnya dilakukan penyeleksian tim pembelajaran dan setiap tim bertanggung jawab terhadap topik yang berbeda-beda. Kemudian setiap anggota kelompok juga diberi topik kecil yang berbeda dan wajib mempresentasikan topik kecilnya tersebut kepada teman satu kelompoknya. Setelah semua topik kecil dipadukan, dilakukan presentasi kelompok sehingga tercipta diskusi antar kelompok dan diakhiri oleh evaluasi baik oleh siswa maupun guru.

Model pembelajaran kooperatif Co-op Co-op merupakan satu di antara berbagai model pembelajaran cooperative learning. Model pembelajaran ini menempatkan tim dalam koperasi antara satu dengan lainnya untuk mempelajari sebuah topik di kelas. Co-op Co-op memberi kesempatan pada siswa untuk bekerja sama dalam kelompok-kelompok kecil, bertujuan untuk meningkatkan pemahaman tentang diri siswa sendiri dan dunia, dan selanjutnya memberikan siswa kesempatan untuk saling berbagi pemahaman baru itu dengan teman-teman sekelasnya (Alirezaei \& KhoshAlhan, 2014; Maryanti, 2018; Sunanto et al., 2020). Model pembelajaran Kooperatif Co-Op Co-Op merupakan salah satu dari banyak cara yang bisa dilakukan guru dalam upaya meningkatkan mutu pembelajaran. Menurut (Andriyani \& Saputra, 2019; Henri et al., 2018; Yeshy et al., 2017) mengemukakan Co-Op Co-Op menempatkan kelompok dalam kooperasi antara satu dengan yang lainnya dan dalam kegiatan di kelas yang lebih mengutamakan diskusi kelompok dan antar kelompok untuk mengembangkan pemahamannya melalui berbagai kegiatan dan pengalaman yang dilakukan siswa.

Model ini mempunyai langkah-langkah yang mendorong keaktifan siswa dalam belajar dengan cara memberikan kesempatan bagi siswa untuk siap tampil di hadapan teman-temannya. Untuk mampu tampil dihadapan orang banyak bukanlah hal yang gampang, mengingat pembelajaran di masa pandemi seperti ini sudah selayaknya tampil di depan kelas diaplikasikan dengan pembuatan video yang mampu ditampilkan di grup pembelajaran. Hal itu memerlukan persiapan yang matang dengan memberi kesempatan agar siswa menyiapkan sebaik-baiknya apa yang akan ditampilkan di hadapan siswa-siswa yang lain. Model pembelajaran Kooperatif Co-Op Co-Op ini mampu merangsang siswa untuk dapat bertanggung jawab terhadap pekerjaannya, menuntut persiapan yang sangat matang, menuntut kemampuan yang matang dalam presentasi, menutut semangat yang tinggi untuk mengikuti pelajaran agar dapat mempersiapkan tampilan yang diharapkan, menuntut sebab akibat dari pelaksanaan diskusi (Alirezaei \& KhoshAlhan, 2014; Maryanti, 2018; Sunanto et al., 2020). Contoh sebab akibat tersebut adalah, apabila siswa giat mengikuti pelajaran maka ia mampu memberi tampilan yang diharapkan. Siswa 
akan menjadi aktif akibat diberikan giliran untuk berbicara di depan teman-temannya, yang sudah pasti akan menimbulkan tuntutan-tuntutan kemampuan yang tinggi baik dalam penampilan maupun keilmuan. Tanpa keilmuan yang mencukupi tidak akan mungkin tampilannya akan memuaskan, dalam hal ini siswa tidak bisa sembarangan saja, mereka harus betul-betul mampu menyimpulkan terlebih dahulu apa yang mereka akan bicarakan. Hal ini menunjukkan bahwa hasil belajar siswa juga lebih baik setelah menggunakan model kooperatif tipe Co-Op Co-Op.

Dari uraian singkat ini jelas bahwa model pembelajaran kooperatif $\mathrm{Co}-\mathrm{Op}$ Co-Op menuntut kemampuan siswa untuk giat mempelajari apa yang disampaikan guru, mampu menampilkan dirinya di depan siswa-siswa yang lain. Di pihak lain, untuk dapat menyelesaikan tuntutan tersebut, inovasi yang dilakukan guru akan sangat menentukan. Inovasi tersebut berupa tuntunan-tuntunan, motivasi-motivasi, interpretasi serta kemampuan implementasi yang tinggi. Cara inilah yang dapat digunakan sebagai dasar pemecahan masalah yang ada. Oleh karenanya penelitian ini sangat penting untuk dilaksanakan.

Penelitian ini didukung dengan penelitian-penelitian sebelumnya yang relevan yaitu, pertama penelitian yang dilakukan oleh (Sunanto et al., 2020), yang mendapatkan hasil penelitian bahwa model pembelajaran kooperatif $\mathrm{Co}-\mathrm{Op}$ Co-Op dan proyek matematika berpengaruh terhadap kemampuan pemecahan masalah. Kedua penelitian yang dilakukan oleh (Yeshy et al., 2017), yang mendapatkan hasil penelitian bahwa model pembelajaran kooperatif tipe Co-Op Co-Op berpengaruh terhadap kemampuan untuk pemecahan masalah siswa muatan pelajaran matematika. Ketiga penelitian yang dilakukan oleh (Henri et al., 2018), yang mendapatkan hasil penelitian bahwa model pembelajaran kooperatif $\mathrm{Co}-\mathrm{Op} \mathrm{Co}$ $O p$ mandiri berpengaruh terhadap kemampuan pemecahan masalah yang ditinjau dari gaya belajar siswa.

Tujuan penelitian penelitian tindakan kelas ini adalah untuk menganalisis penerapan model pembelajaran kooperatif $\mathrm{Co}-\mathrm{Op} \mathrm{Co}-\mathrm{Op}$ untuk meningkatkan prestasi belajar yadnya secara online di SMK Negeri 2 Singaraja pada tahun ajaran 2020/2021.

\section{Metode}

Penelitian ini termasuk kedalam jenis penelitian tindakan kelas. Penelitian ini dilaksanakan di SMK Negeri 2 Singaraja pada tahun ajaran 2020/2021. Sekolah ini berlokasi di Jalan Srikandi nomor 9 Singaraja. Di sekolah ini, peneliti menemukan masalah seperti yang tertuang di dalam latar belakang masalah di atas. Dengan permasalahan tersebut, maka peneliti memilih tempat ini yaitu SMK Negeri 2 Singaraja sebagai tempat untuk mengadakan penelitian.

Penelitian ini dilaksanakan pada semester ganjil tahun pelajaran 2020/2021 dilaksanakan dari bulan Juli sampai dengan bulan Agustus 2020. Subyek penelitian adalah siswa kelas X Kuliner 4 SMK Negeri 2 Singaraja yang berjumlah 32 orang siswa, yang terdiri dari 13 orang laki-laki dan 19 Perempuan. Sedangkan objek dari penelitian ini adalah prestasi belajar yadnya mata pelajaran Agama Hindu dan Budi Pekerti siswa kelas X Kuliner 4 SMK Negeri 2 Singaraja.

Metode pengumpulan datanya adalah pemberian tes prestasi belajar kepada siswa. Penelitian ini akan berlangsung melalui beberapa siklus sesuai dengan waktu dan hasil yang di capai atau diinginkan. Dengan demikian pada siklus ke-n target yang diinginkan sudah harus tercapai. Pada setiap siklus terdapat beberapa tahapan kegiatan. Salah satu karakteristik penelitian tindakan kelas adalah adanya proses pelaksanaan penelitian sebagai ada informasi yang merupakan balikan dari apa yang telah dilakukan oleh si peneliti (Ragil \& Sukiswo, 2011; Suratno, 2013; Yampap \& Bay, 2020). Proses tersebut merupakan proses yang dinamis dimana ada empat tahap, yaitu: (1) perencanaan tindakan; (2) pelaksanaan tindakan; (3) observasi yang dilanjutkan dengan analisis dan evaluasi; dan (4) refleksi.

Teknik analisis datanya adalah deskriptif kuantitatif yang dilakukan dalam tiga tahapan, yaitu reduksi data, paparan data, dan penyimpulan hasil analisis. Sedangkan analisis kuantitatif hanya sebagai penunjang data untuk dapat memperkuat argumentasi atau paparan naratif.

\section{Hasil dan Pembahasan}

Berdasarkan tes awal yang diberikan kepada siswa didapatkan prestasi belajar Agama Hindu pada materi yadnya sebesar 68,44 dengan ketuntasan belajar 59,38\% sehingga berada pada kategori rendah. Atas dasar di atas, dipandang perlu adanya perbaikan pelaksanaan proses pembelajaran yang menekankan pada perbaikan pendekatan dan perbaikan pada penggunaan metode pembelajaran yang dikemas dalam model pembelajaran yang inovatif yang dirancang dalam sistem siklus.

Berdasarkan penelitian yang telah dilakukan pada siklus I, didapatkan hasil sebagai berikut. Prestasi belajar siswa mendapatkan rata-rata kelas sebesar 71,56 dengan daya serap 71,56\% serta ketuntasan belajar sebesar $68,75 \%$ hal ini berarti masih dibawah target yang diinginkan yaitu rerata kelas 
70, daya serap $70 \%$ dan ketuntasan belajar $80 \%$ berdasarkan data tersebut di atas, maka langkah perbaikan harus tetap dilakukan pada siklus II.

Berpijak dari hasil penelitian terhadap pelaksanaan tindakan pertama ada beberapa hal yang dapat peneliti jadikan catatan, diawal pertemuan banyak siswa belum siap dalam mengikuti pelajaran. Hal itu terbukti dari ketidakmampuan siswa untuk menjawab latihan-latihan sesuai dengan pokok bahasan. Padahal tujuan dari hal tersebut adalah untuk membantu pemahaman siswa dalam hubungannya dengan penguasaan dan pemahaman materi yang terdapat dalam pokok bahasan dalam pembelajaran. Ketidaksiapan siswa lebih tampak lagi pada saat guru pengajar memberikan soal-soal pre-test maupun post test untuk dikerjakan oleh siswa secara individual, banyak siswa kaget dan kebingungan untuk mencari jawaban baik dari buku maupun bertanya kepada temannya. Mengatasi hal ini, guru mencoba memberikan pengarahan tentang maksud dan tujuan diberikannya soal-soal pre-tes, maupun post tes namun itu semua tidak berpengaruh banyak terhadap proses pembelajaran.

Dalam penerapan model pembelajaran kooperatif Co-Op Co-Op, memang banyak memiliki kelebihan dan juga memiliki kelemahan. Adapun beberapa kelemahan yang dijumpai dalam tindakan siklus pertama ini yang harus disempurnakan dalam siklus kedua yaitu: (a) masih banyak siswa yang ragu-ragu dalam memberikan tanggapan atau jawaban terhadap temannya; (b) jawaban yang diberikan siswa masih sangat sederhana dan terkesan hapalan saja; dan (c) masih ada beberapa siswa kurang mengembangkan kemampuannya secara optimal untuk menjawab semua latihan-latihan soal.

Untuk mengukur kelemahan itu digunakan instrumen pedoman observasi belajar-pembelajaran. Jika dilihat dari beberapa kelemahan di atas, maka dapat mempengaruhi hasil balajar, karena itu peneliti berkolaborasi dengan guru pengajar akan mengadakan suatu alternatif pemecahan dan perbaikan tindakan pada siklus pertama ini yang terlebih dahulu telah didiskusikan dengan siswa, berupa: (a) guru pengajar memberikan motivasi kepada siswa agar memunculkan rasa percaya diri dan keberanian dalam setiap menjawab latihan-latihan soal; (b) guru pengajar akan mengajak siswa untuk mnjawab latihanlatihan, lebih banyak mengembangkan kemampuan afektif siswa, serta kembali menekankan konsep belajar yang mandiri serta aktif; dan (c) guru pengajar akan berkeliling pada saat siswa mengerjakan latihan-latihan soal sehingga dapat memantau kegiatan siswa jika mengalami kesulitan.

Berdasarkan proses pembelajaran yang dilakukan pada siklus II, terlihat bahwa proses pembelajaran sudah semakin baik. Hal ini terbukti pada siklus II sudah memenuhi target. Hal ini dapat dilihat dari data sebagai berikut prestasi belajar dimana rata-rata kelas sebesar 81,09 dengan daya serap $81,09 \%$ serta ketuntasan belajar sebesar $96,88 \%$ hal ini berarti sudah memenuhi target bahkan sudah melebihi target yang diinginkan yaitu rerata kelas 70 , daya serap $70 \%$ dan ketuntasan belajar $80 \%$. Kenyataan ini menunjukan bahwa hasil penelitian telah melampaui target yang diinginkan. Hal ini disebabkan oleh: (1) penerapan model pembelajaran kooperatif Co-Op Co-Op dapat dilaksanakan secara efektif; (2) suasana pembelajaran yang kondusif; (3) pembelajaran berorientasi pada siswa; dan (4) adanya bimbingan belajar.

Pembelajaran kooperatif tipe $\mathrm{Co}-\mathrm{Op}$ Co-Op adalah pembelajaran yang mengutamakan diskusi kelompok dan diskusi antar kelompok (Andriyani \& Saputra, 2019; Togatorop, 2017; Yeshy et al., 2017). Pada awal pembelajaran dilakukan diskusi kelas yang berpusat pada siswa. Selanjutnya dilakukan penyeleksian tim pembelajaran dan setiap tim bertanggung jawab terhadap topik yang berbeda-beda. Kemudian setiap anggota kelompok juga diberi topik kecil yang berbeda dan wajib mempresentasikan topik kecilnya tersebut kepada teman satu kelompoknya. Setelah semua topik kecil dipadukan, dilakukan presentasi kelompok sehingga tercipta diskusi antar kelompok dan diakhiri oleh evaluasi baik oleh siswa maupun guru.

Model pembelajaran kooperatif Co-op Co-op merupakan satu di antara berbagai model pembelajaran cooperative learning. Model pembelajaran ini menempatkan tim dalam koperasi antara satu dengan lainnya untuk mempelajari sebuah topik di kelas. Co-op Co-op memberi kesempatan pada siswa untuk bekerja sama dalam kelompok-kelompok kecil, bertujuan untuk meningkatkan pemahaman tentang diri siswa sendiri dan dunia, dan selanjutnya memberikan siswa kesempatan untuk saling berbagi pemahaman baru itu dengan teman-teman sekelasnya (Alirezaei \& KhoshAlhan, 2014; Maryanti, 2018; Sunanto et al., 2020). Model pembelajaran Kooperatif $\mathrm{Co}-\mathrm{Op}$ Co-Op merupakan salah satu dari banyak cara yang bisa dilakukan guru dalam upaya meningkatkan mutu pembelajaran. Menurut (Andriyani \& Saputra, 2019; Henri et al., 2018; Yeshy et al., 2017) mengemukakan Co-Op Co-Op menempatkan kelompok dalam kooperasi antara satu dengan yang lainnya dan dalam kegiatan di kelas yang lebih mengutamakan diskusi kelompok dan antar kelompok untuk mengembangkan pemahamannya melalui berbagai kegiatan dan pengalaman yang dilakukan siswa.

Penelitian ini didukung dengan penelitian-penelitian sebelumnya yang relevan yaitu, pertama penelitian yang dilakukan oleh (Sunanto et al., 2020), yang mendapatkan hasil penelitian bahwa model pembelajaran kooperatif $\mathrm{Co}-\mathrm{Op}$ Co-Op dan proyek matematika berpengaruh terhadap kemampuan 
pemecahan masalah. Kedua penelitian yang dilakukan oleh (Yeshy et al., 2017), yang mendapatkan hasil penelitian bahwa model pembelajaran kooperatif tipe Co-Op Co-Op berpengaruh terhadap kemampuan untuk pemecahan masalah siswa muatan pelajaran matematika. Ketiga penelitian yang dilakukan oleh (Henri et al., 2018), yang mendapatkan hasil penelitian bahwa model pembelajaran kooperatif $\mathrm{Co}-\mathrm{Op} \mathrm{Co}$ $O p$ mandiri berpengaruh terhadap kemampuan pemecahan masalah yang ditinjau dari gaya belajar siswa.

Implikasi penelitian ini adalah penerapan model pembelajaran kooperatif Co-Op Co-Op dapat melatih siswa agar aktif, antusias didalam pembelajaran dan dapat memahami materi yang diajarkan sehingga prestasi belajar siswa menjadi meningkat.

\section{Simpulan}

Berdasarkan penelitian yang telah dilakukan, dan analisis hasil dan pembahasan dapat disimpulkan bahwa model pembelajaran Kooperatif Co-Op Co-Op dapat meningkatkan prestasi belajar yadnya secara online di SMK Negeri 2 Singaraja pada tahun ajaran 2020/2021. Implikasi penelitian ini adalah penerapan model pembelajaran kooperatif Co-Op Co-Op dapat melatih siswa agar aktif, antusias didalam pembelajaran dan dapat memahami materi yang diajarkan sehingga prestasi belajar siswa menjadi meningkat.

\section{Daftar Rujukan}

Alirezaei, A., \& KhoshAlhan, F. (2014). Coordination of pricing and co-op advertising models in supply chain: A game theoretic approach. International Journal of Industrial Engineering Computations, 5(1), 23-40. https://doi.org/10.5267/j.ijiec.2013.09.006.

Andriyani, R., \& Saputra, N. N. (2019). Penerapan Pembelajaran Kooperatif Tipe Co-Op Co-Op Dalam Pembelajaran Matematika Siswa Kelas X Pemasaran SMKN 3 Padang. Prima: Jurnal Pendidikan Matematika, 6(1), 13-19. https://doi.org/10.31000/prima.v6i1.1464.

Anggreni, N. M. (2016). Konstruksi Budaya Mutu Relevansinya Dengan Manajemen Mutu Guru Dalam Pembelajaran Pendidikan Agama Hindu. Jurnal Penjaminan Mutu, 2(2), 84-92. https://doi.org/10.25078/jpm.v2i2.75.

Ardianingsih, F., Mahmudah, S., \& Rianto, E. (2017). Peran Guru Dalam Implementasi Kurikulum 2013 Pendidikan Khusus Pada Sekolah Luar Biasa Di Sidoarjo. Jurnal Pendidikan, 2(1), 14-20. https://doi.org/10.26740/jp.v2n1.p21-30.

Cahyaningsih, U. (2018). Penerapan Model Pembelajaran Kooperatif Tipe Tai (Team Assisted Individualization) Untuk Meningkatkan Hasil Belajar Siswa Pada Mata Pelajaran Matematika. Jurnal Cakrawala Pendas, 4(1). https://doi.org/10.31949/jcp.v4i1.707.

Gateri, N. W. (2016). Ajaran Agama Hindu Dalam Peningkatan Kerukunan Rumah Tangga Menuju Keharmonisan Hidup. Jurnal Penjaminan Mutu, 2(2), 93-108. https://doi.org/10.25078/jpm.v2i2.76.

Henri, H., Syamsurizal, S., \& Syaiful, S. (2018). Model Co-Op Co-Op Mandiri Terhadap Kemampuan Pemecahan Masalah Ditinjau Dari Gaya Belajar Siswa. Jurnal Aksioma, 7(3). https://doi.org/10.24127/ajpm.v7i3.1583..

Karom, D., Ruhimat, T., \& Darmawan, D. (2014). Pengaruh Kompetensi Pedagogik Guru Dalam Menerapkan Pembelajaran Kooperatif Berbantuan Media Presentasi Terhadap Hasil Belajar Peserta Didik Pada Mata Pelajaran Matematika. Edutech, 13(2), 274-308. https://doi.org/10.17509/edutech.v13i2.3113.

Khodijah, N. (2018). Pendidikan Karakter Dalam Kultur Islam Melayu (Studi Terhadap Pola Asuh Orang Tua, Faktor-Faktor Yang Mempengaruhinya, Dan Pengaruhnya Terhadap Religiusitas Remaja Pada Suku Melayu Palembang). Tadrib: Jurnal Pendidikan Agama Islam, 4(1), 21-39. https://doi.org/10.19109/tadrib.v4i1.1949.

Lestari, I. (2018). Penerapan Metode Pembelajaran Diskusi Dan Resitasi Dalam Meningkatkan Hasil Belajar Pendidikan Agama Hindu Siswa Kelas Iv Sd Negeri 2 Tumbu Karangasem. Jurnal Penjaminan Mutu, 4. http://ejournal.ihdn.ac.id/index.php/JPM/article/view/398.

Makaborang, Y. (2019). Evaluasi Implementasi Kurikulum 2013 Mata Pelajaran Biologi Di SMA Negeri. Kelola: Jurnal Manajemen Pendidikan, 6(2), 130-145. 
https://doi.org/10.24246/j.jk.2019.v6.i2.p130-145.

Mamanda, S. (2018). Penerapan Model Pembelajaran Kooperatif Tipe Teams Game Tournaments (TGT) untuk Meningkatkan Hasil Belajar Ilmu Pengetahuan Sosial. Jurnal Penelitian Dan Pengembangan Pendidikan, 2(3), 256. https://doi.org/10.23887/jppp.v2i3.16283.

Maryanti, S. (2018). Model Pembelajaran Kooperatif Co-Op Co-Op dengan Pendekatan Predict-ObserveExplain untuk Meningkatkan Kemampuan Pemecahan Masalah Matematis. DESIMAL, 1(3), 293302. https://doi.org/10.24042/djm.v1i3.2680.

Murdika. (2018). Penerapan Model Pembelajaran Kooperatif Tipe TGT Untuk Meningkatkan Motivasi dan Aktivitas Belajar Peserta Didik Kelas XMIA-3 SMAN 1 Tanete Rilau (Studi pada Materi Pokok Ikatan Kimia dan Bentuk Geometri). Chemica: Jurnal Ilmiah Kimia Dan Pendidikan Kimia, 19(1), 75. https://doi.org/10.35580/chemica.v19i1.6647.

Naldi, F., \& Susanti, A. (2018). Pengaruh Model Pembelajaran Co-op Co-op terhadap Pemahaman Konsep Ditinjau dari Gaya Belajar Visual, Audio, Kinestetik Siswa Kelas VIII SMPN 43 Merangin. Edumatica: Jurnal Pendidikan Matematika, 8(1). https://doi.org/10.22437/edumatica.v8i01.4115.

Purwanti, K. L. (2017). Penerapan Literasi Lintas Kurikulum Matematika Dalam Pembelajaran Kelas Tinggi Di MIT Nurul Islam Ngaliyan Semarang Tahun 2016. Phenomenon : Jurnal Pendidikan MIPA, 7(1), 79. https://doi.org/10.21580/phen.2017.7.1.1497.

Ragil, Z., \& Sukiswo, S. E. (2011). Penerapan Pembelajaran Sains Dengan Pendekatan Sets Pada Materi Cahaya Untuk Meningkatkan Hasil Belajar Siswa Kelas V Sd. Jurnal Pendidikan Fisika Indonesia, 7(1), 69-73. https://doi.org/10.15294/jpfi.v7i1.1073.

Santriana Son, R. S. (2019). Pengaruh Model Pembelajaran Kooperatif Tipe Time Token Terhadap Hasil Belajar Siswa SMP. Scholaria: Jurnal Pendidikan Dan Kebudayaan, 9(3), 284-291. https://doi.org/10.24246/j.js.2019.v9.i3.p284-291.

Selasih, N. N. (2016). Peranan Sentral Guru Agama Hindu Dalam Pencapaian Tujuan Pendidikan Nasional Di Indonesia Dan Pembangunan Karakter Bangsa Yang Berakhlak Mulia, Jujur, Terampil, Berhati Suci Dan Bersih Lahir Batin. Jurnal Penjaminan Mutu, 1(1), 54-66. https://doaj.org/article/7edf88ce42984adc93dcc576eacee5d3.

Setyaningsih, S., Rusijono, R., \& Wahyudi, A. (2020). Pengaruh Penggunaan Media Pembelajaran Interaktif Berbasis Articulate Storyline Terhadap Motivasi Belajar dan Hasil Belajar Siswa Pada Materi Kerajaan Hindu Budha di Indonesia. Didaktis: Jurnal Pendidikan Dan Ilmu Pengetahuan, 20(2), 144-156. https://doi.org/10.30651/didaktis.v20i2.4772.

Sihombing, L. (2018). Upaya Meningkatkan Motivasi Belajar PKN Siswa Kelas VII.4 Melalui Penerapan Model Pembelajaran Kooperatif Dengan Teknik Keliling Kelas Di SMP Negeri 21 Pekanbaru. Dinamisia-Jurnal Pengabdian Kepada Masyarakat, 2(1), 84-90. https://doi.org/10.31849/dinamisia.v2i1.1095.

Suanthara, I. N. D. E. (2018). Pengaruh Model Pembelajaran Tri Kaya Parisudha Terhadap Prestasi Belajar Mahasiswa Semester V Prodi Pendidikan Agama Hindu STKIP Agama Hindu Singaraja Tahun Akademik 2016/2017. Pasupati: Journal of Hindu Studies \& Ducation, 5(2). https://doi.org/10.37428/pspt.v5i2.31.

Sukrawati, N. M. (2018). Pendidikan Acara Agama Hindu: Antara Tradisi dan Modernitas. DHARMASMRTI, 18(2), 43-49. https://doi.org/10.32795/ds.v9i2.145.

Sunanto, R. F., Apriliani, R., \& Nafi'ah, W. (2020). Students' Mathematical Problem Solving Abilities: The Impact of The Co-Op Co-Op Cooperative Learning Model and Missouri Mathematics Project. DESIMAL, 3(3), 279-286. https://doi.org/10.24042/djm.v3i3.7332.

Suparmi, S. (2013). Pembelajaran Kooperatif dalam Pendidikan Multikultural. Jurnal Pembangunan Pendidikan: Fondasi Dan Aplikasi, 1(1), 108-118. https://doi.org/10.21831/jppfa.v1i1.1055

Suratno. (2013). Pengaruh Penerapan Metode STAD Terhadap Hasil Belajar Ekonomi Ditinjau Dari Minat Siswa Di SMA N 10 Batanghari. Jurnal Pendidikan Ekonomi Dinamika Pendidikan, 8(2), 111-122. https://doi.org/10.15294/dp.v8i2.3367.

Suryanata, I. K. A. (2017). Pengaruh Model Pembelajaran Kooperatif Tipe Teams Games Tournament Terhadap Hasil Belajar Matematika. JKPM (Jurnal Kajian Pendidikan Matematika), 2(2), 235. 
https://doi.org/10.30998/jkpm.v2i2.2497.

Togatorop, M. (2017). Pengembangan Model Pembelajaran Co-Op Co-Op Berbantu Teknologi Inforamsi Dan Komunikasi (TIK) Pada Mata Pelajaran Ekonomi. Satya Widya, 33(2), 128-145. https://doi.org/10.24246/j.sw.2017.v33.i2.p128-145.

Widyanto, I. P. (2020). Peningkatan Mutu Pendidikan Hindu Melalui Pengelolaan Pembelajaran. Jurnal Penjaminan Mutu, 6(1), 48-59. https://doi.org/http://dx.doi.org/10.25078/jpm.v6i1.1151.

Wintari, N. L. M. D., Wiyasa, I. K. N., \& Putra, M. (2014). Implementasi Model Pembelajaran Kooperatif Tipe Team-Assisted Individualization (TAI) Dalam Upaya Meningkatkan Interaksi Dan Hasil Belajar Matematika Siswa Kelas IV SD Negeri 6 Dauh Puri Tahun Pelajaran 2013/2014. Mimbar PGSD Undiksha, 2(1). https://doi.org/10.23887/jjpgsd.v2i1.3093.

Yampap, U., \& Bay, H. R. (2020). Penerapan Pendekatan Keterampilan Proses untuk Meningkatkan Keterampilan Berpikir Kritis Siswa Sekolah Dasar. Musamus Journal of Primary Education, 3(1), 57-64. https://doi.org/10.35724/musjpe.v3i1.3201.

Yeshy, Y., Nirawati, R., \& Husna, N. (2017). Pengaruh Model Pembelajaran Kooperatif Tipe Cooperation In Education (Co-Op Co-Op) Terhadap Kemampuan Pemecahan Masalah Matematis Siswa Pada Materi Kubus Dan Balok. JPMI (Jurnal Pendidikan Matematika Indonesia), 2(1), 19-26. https://doi.org/10.26737/jpmi.v2i1.209. 